\title{
Meta
}

Journal des traducteurs

Translators' Journal

\section{How to Say Things with Words: Ways of Saying in English and Spanish}

\section{Ana Rojo et Javier Valenzuela}

Volume 46, numéro 3, septembre 2001

URI : https://id.erudit.org/iderudit/003971ar

DOI : https://doi.org/10.7202/003971ar

Aller au sommaire du numéro

\section{Éditeur(s)}

Les Presses de l'Université de Montréal

ISSN

0026-0452 (imprimé)

1492-1421 (numérique)

Découvrir la revue

Citer cet article

Rojo, A. \& Valenzuela, J. (2001). How to Say Things with Words: Ways of Saying in English and Spanish. Meta, 46(3), 467-477. https://doi.org/10.7202/003971ar
Résumé de l'article

Slobin a remarqué les différences entre les verbes de mouvement en espagnol et en anglais, en ce qui concerne l'expression d'éléments comme le « trajet du mouvement ", ou sa « modalité ». En général, les verbes anglais incorporent la " modalité » dans le noyau de leur sens alors que les verbes espagnols ont tendance à incorporer le " trajet » et à exprimer la " modalité " avec un complément additionnel. En comparant les évènements de mouvement en anglais et leurs traductions en espagnol dans différents romans, Slobin a observé que seulement $51 \%$ des verbes exprimant la modalité étaient traduits à l'espagnol par des verbes de manière, les autres demeurant neutralisés ou omis. Nous avons l'intention d'appliquer l'analyse de Slobin aux verbes de langue, en anglais et en espagnol. Notre travail étudiera les systèmes d'agglutination des verbes en anglais et en espagnol ainsi que la méthode de traduction de ces verbes adoptée par les traducteurs espagnols.
Tous droits réservés @ Les Presses de l'Université de Montréal, 2001
Ce document est protégé par la loi sur le droit d'auteur. L'utilisation des services d'Érudit (y compris la reproduction) est assujettie à sa politique d'utilisation que vous pouvez consulter en ligne.

https://apropos.erudit.org/fr/usagers/politique-dutilisation/ 


\title{
How to Say Things with Words: Ways of Saying in English and Spanish
}

\author{
ANA ROJO and JAVIER VALENZUELA \\ University of Murcia, Murcia, Spain
}

\begin{abstract}
RÉSUMÉ
Slobin a remarqué les différences entre les verbes de mouvement en espagnol et en anglais, en ce qui concerne l'expression d'éléments comme le «trajet du mouvement », ou sa «modalité». En général, les verbes anglais incorporent la «modalité» dans le noyau de leur sens alors que les verbes espagnols ont tendance à incorporer le «trajet » et à exprimer la «modalité » avec un complément additionnel. En comparant les évènements de mouvement en anglais et leurs traductions en espagnol dans différents romans, Slobin a observé que seulement $51 \%$ des verbes exprimant la modalité étaient traduits à l'espagnol par des verbes de manière, les autres demeurant neutralisés ou omis. Nous avons l'intention d'appliquer l'analyse de Slobin aux verbes de langue, en anglais et en espagnol. Notre travail étudiera les systèmes d'agglutination des verbes en anglais et en espagnol ainsi que la méthode de traduction de ces verbes adoptée par les traducteurs espagnols.
\end{abstract}

\section{ABSTRACT}

Slobin $(1997,1998)$ has pointed out the differences between Spanish and English verbs of motion with regard to the expression of elements such as "Path of motion" or "Manner of motion." Generally speaking, English verbs incorporate manner to their core meaning while Spanish verbs tend to incorporate Path, expressing Manner with an additional complement. Comparing English motion events and their translation into Spanish in several novels, Slobin found out that only $51 \%$ of English manner verbs were translated into Spanish manner verbs (Slobin 1996), the rest being neutralized or omitted. We intend to apply Slobin's analysis to verbs of saying in English and Spanish. Our work aims to analyze the conflation patterns of verbs of saying in English and Spanish and the way Spanish translators deal with them.

\section{MOTS-CLÉS/KEY WORDS}

frame semantics, manner of motion, manner verbs, novels, path of motion

\section{Introduction}

Fillmore's Frame Semantics has argued that the meaning of a word is more than just a list of attributes. In his theory, words can only be adequately described by making reference to a "structured background of experience, beliefs or practices, constituting a kind of conceptual pre-requisite for understanding the meaning" (Fillmore \& Atkins, 1992: 76). This "structured background" is what Fillmore calls a "frame." In recent years, Fillmore has applied this notion to the study of verbs, mainly with lexicographic purposes (Baker, Fillmore \& Lowe, 1998; Fillmore \& Atkins, 1992, 1994).

The American psychologist Dan Slobin has studied verbs of motion using Fillmore's frames. In one of his most influential papers, Slobin (1996) analyzes the different expression of motion by English and Spanish speakers. Following Talmy's 
insights (Talmy, 1991), Slobin classifies English and Spanish in two different language typologies: English is a "satellite-framed" language, while Spanish is a "verbframed" language. What this means is that these two languages differ as to the linguistic expression of the different frame elements in a motion event. Thus, Spanish verbs tend to encode (to "incorporate" or "conflate") in their lexical meaning the notion of PATH (e.g., subir, bajar, entrar, salir, etc.), while English verbs tend to incorporate MANNER OF MOTION (e.g., shuffle, tip-toe, crawl, etc.). To express PATH in English, one must use a separate word, a "satellite": to go in/up/down; to express MANNER OF MOTION in Spanish, one must very often resort to "external" arguments to the verb, as with an adverbial phrase, etc. (e.g., andar arrastrando los pies, andar de puntillas, etc.).

In Slobin (1996), he examined the consequences of this typological difference for the narrative styles of both languages. Looking at a number of English and Spanish novels and their translations, he concluded that English has a much higher number of motion verbs which incorporate manner than Spanish. Relating this to Talmy's verb typologies, he mentions that "S-languages will have a larger and more diverse lexicon of manner verbs in comparison with V-languages"' (Slobin, 1997: 458).

Slobin noticed that this difference in the number and nature of the lexicon of manner verbs posed particular problems for translators in both directions. For instance, in Slobin (1996) he found out that only 51\% of English manner verbs were translated into Spanish manner verbs. In the remaining cases, information about manner was either omitted or neutralized. Going from Spanish into English, he observed that it was frequent for translators to add manner information which was not lexically incorporated in the Spanish motion verb.

In this study, we intend to examine whether Slobin's results also apply to verbs of saying. Verbs of saying can also incorporate manner both in English (e.g., to shout, to murmur) and Spanish (e.g., gritar, murmurar). We will look at the information that is codified by English and Spanish verbs of saying, in order to see to which degree that information is either lost or gained when going from one language to the other.

\section{Study}

\subsection{Aim}

The aim of our study is to analyze the conflation patterns of verbs of saying in English and the way Spanish translators deal with them. In particular, we attempt to focus on any possible gain or loss of information during the translation process. We also intend to look into the nature of this particular information using Frame Semantics as an analytic tool.

\subsection{Material and Methods}

In order to carry out our study, we chose as a corpus of analysis four English contemporary novels and their translations into Spanish. The selected novels were:

The Buddha of Suburbia, by Hanif Kureishi

El Buda de los Suburbios (translated by Mónica Martín Berdagué) 
Small World, by David Lodge

El Mundo es un pañuelo (translated by Esteban Riambau Saurí)

Leviathan, by Paul Auster

Leviathan (translated by Maribel de Juan)

Money, by Martin Amis

Dinero (translated by Enrique Murillo)

We extracted 100 verbs of saying from each novel (four hundred verbs in total) and their corresponding translations into Spanish. The verbs were selected randomly: one page was chosen at random and all the verbs of saying were noted down up to a hundred.

In order to investigate the gain or loss of information due to differences in the conflation patterns of English and Spanish verbs, we divided the verbs into two broad groups:

(1) General verbs of saying: we considered as general those verbs which basically included the two main frame elements in a communicative event, the Speaker and the Addressee. Some examples of this category would be to say, to speak, to talk, etc.

(2) Specific verbs: a verb was considered specific whenever reference to any other element in the communicative frame was made. Examples of this category include to shout, to murmur, etc.

DIAGRAM 1

Frame elements activated by four different verbs of saying
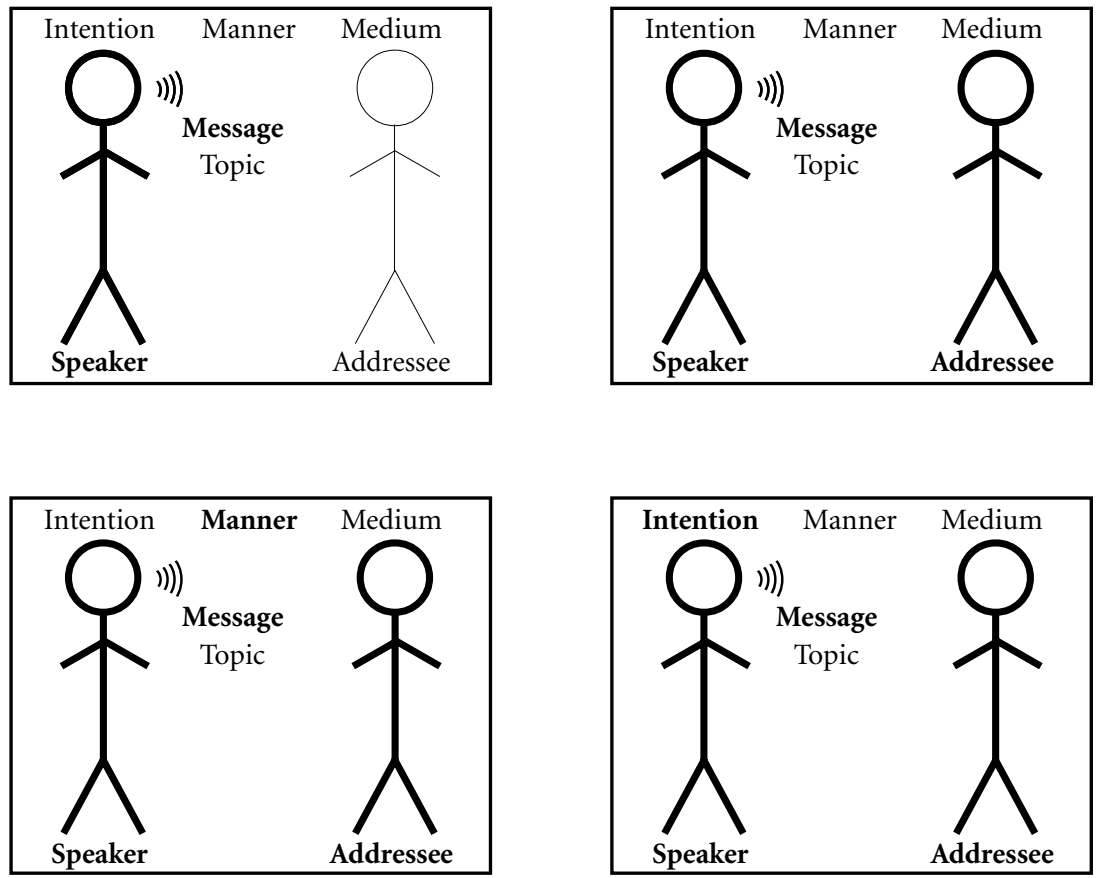
Then we proceeded to study what strategies Spanish translators used when dealing with these two categories of verbs.

\subsection{Results}

The English and Spanish verbs of saying found in the novels were:

English:

add, admit, agree, announce, answer, ask, call, claim, clammer, confess, continue, coo, croak, cry, curse, chat, declaim, declare, discuss, elaborate, enquire, exclaim, explain, gasp, growl, grunt, hum, inquire, mention, murmur, promise, quip, quote, ramble, refer, remark, reply, resume, say, shout, soften, speak, spell, suggest, talk, tease, tell, urge, volunteer, yell

Spanish:

acceder, aclarar, aconsejar, admitir, afirmar, anunciar, añadir, asegurar, bromear, canturrear, citar, clamar, comentar, comunicar, confesar, contar, contestar, continuar, croar, charlar, decir, declamar, declarar, defenderse, divagar, empezar a hablar, exclamar, explicar, felicitar, gritar, gruñir, hablar, hacer, inquirir, insistir, invitar, lamentarse, limitarse a contestar, llamar, llegar a decir, mencionar, murmurar, observar, ordenar, pedir, precisar, preguntar, proclamar, prometer, proponer, provocar, quejarse, referir, referirse, repetir, reponer, responder, rogar, sugerir, terciar

In total, the number of Spanish verbs of saying found was slightly higher than that of English verbs. Spanish translators used sixty different Spanish verbs to translate the fifty verbs used in the English novels.

Out of the English verbs, four were classified as general (say, speak, talk and tell) and the rest as specific. In the Spanish list, contar, decir, hablar and charlar were considered general and the rest were considered specific.

In our corpus, four different strategies used by Spanish translators were observed:

(1) A general verb in English translated for a general verb in Spanish $($ GEN $\rightarrow$ GEN)

(2) A specific verb in English translated for a specific verb in Spanish $($ SPEC $\rightarrow$ SPEC)

(3) A general verb in English translated for a specific verb in Spanish $(\mathrm{GEN} \rightarrow$ SPEC)

(4) A specific verb in English translated for a general verb in Spanish $($ SPEC $\rightarrow$ GEN)

For reasons of brevity, we do not offer here the full-fledged translation of all the examples analyzed; instead, we provide the following tables with the English general and specific verbs and the Spanish verbs used in their translation: 
TABLE 1

General English verbs translated by general Spanish verbs. The numbers in brackets correspond to the number of times the verb has been used in the translation.

$$
\text { GEN } \rightarrow \text { GEN }
$$

\begin{tabular}{|l|l|}
\hline say & decir (152), hablar, contar \\
\hline speak & contar, decir, hablar (3) \\
\hline talk & charlar, decir, hablar (21) \\
\hline tell & contar (15), decir (22), hablar \\
\hline
\end{tabular}

TABLE 2

Specific English verbs translated by specific Spanish verbs. The numbers in brackets correspond to the number of times the verb has been used in the translation.

\begin{tabular}{|l|l|l|l|}
\multicolumn{5}{|c}{ SPEC $\rightarrow$ SPEC } \\
\hline add & añadir & gasp & soltar un respingo \\
\hline admit & admitir (2) & growl & gruñir \\
\hline agree & admitir (2) & grunt & soltar un gruñido \\
\hline announce & anunciar, comunicar & hum & canturrear \\
\hline answer & responder & hacer preguntas (5), invitar, \\
pedir (3), preguntar (11) & mention & preguntar \\
\hline ask & llamar (5) & murmur & $\begin{array}{l}\text { murmurar, añadir en un } \\
\text { murmullo, preguntar en un } \\
\text { susurro }\end{array}$ \\
\hline call & & & prometer \\
\hline claim & asegurar & promise & bromear \\
\hline clammer & clamar & quip & divagar \\
\hline confess & confesar & ramble on & referir \\
\hline continue & continuar & refer & contestar \\
\hline coo & decir entre arrullos & reply & contestar (3), reponer \\
\hline croak & croar & shout & gritar (4) \\
\hline cry & $\begin{array}{l}\text { exclamar, felicitar, gritar } \\
\text { entre sollozos }\end{array}$ & & añadir en un tono más dulce \\
\hline curse & decir con insultos & soften & ñole \\
\hline chat & charlar & spell & explicar y proceder a deletrear \\
\hline declaim & declamar & suggest & aconsejar, sugerir \\
\hline declare & declarar & tease on & provocar \\
\hline elaborate & añadir para mayor detalle & urge & rogar \\
\hline enquire & inquirir (2), preguntar & volunteer & aclarar \\
\hline exclaim & exclamar & yell & gritar \\
\hline explain & explicar (4) & & \\
\hline
\end{tabular}


TABLE 3

General English verbs translated by specific Spanish verbs. The numbers in brackets correspond to the number of times the verb has been used in the translation.

$$
\mathrm{GEN} \rightarrow \mathrm{SPEC}
$$

\begin{tabular}{|l|l|}
\hline say & $\begin{array}{l}\text { acceder, aclarar, admitir, afirmar, anunciar, añadir, asegurar (3), comentar (3), } \\
\text { contestar (12), defenderse, exclamar (7), explicar (5), hacer, inquirir, insistir (2), } \\
\text { lamentarse (2), limitarse a contestar, llegar a decir, observar (2), ordenar, pedir } \\
\text { (2), precisar (2), preguntar (12), proclamar (2), proponer (2), proponer, } \\
\text { quejarse (3), repetir, reponer (3), responder, sugerir, terciar }\end{array}$ \\
\hline talk & empezar a hablar, referirse, explicar, explicar, repetir \\
\hline tell & explicar, repetir \\
\hline
\end{tabular}

TABLE 4

Specific English verbs translated by general Spanish verbs. The numbers in brackets correspond to the number of times the verb has been used in the translation.

$$
\mathrm{SPEC} \rightarrow \mathrm{GEN}
$$

\begin{tabular}{|l|l|}
\hline ask & decir $(2)$ \\
\hline discuss & hablar $(4)$ \\
\hline resume & decir \\
\hline
\end{tabular}

To find out the distribution of the translation strategies across the four novels, we counted the number of times a strategy was used in each novel; this is the information that appears in Table 5. We also calculated the total number of times each strategy was used in the four novels.

TABLE 5

Translation strategies per novel and total percentage in the four novels

\begin{tabular}{|l|c|c|c|c|c|}
\hline & MONEY & LEVIATHAN & BUDDHA & SMALL WORLD & TOTAL \\
\hline GEN $\rightarrow$ GEN & 77 & 71 & 39 & 33 & $220(55 \%)$ \\
\hline SPEC $\rightarrow$ SPEC & 14 & 25 & 26 & 24 & $89(22.25 \%)$ \\
\hline GEN $\rightarrow$ SPEC & 3 & 4 & 31 & 43 & $83(20.75 \%)$ \\
\hline SPEC $\rightarrow$ GEN & 4 & 0 & 4 & 0 & $8(2 \%)$ \\
\hline
\end{tabular}

\subsection{Discussion}

The translation strategies found throughout the four novels do not correspond exactly to what could be expected from Slobin's work $(1996,1997)$. While it seems hardly surprising that the most frequent strategy is to translate a general verb for another general verb (See Tables 1 and 5), the high number of times the "SPEC $Æ$ SPEC" strategy was used seemed to indicate a different behaviour in verbs of saying with respect to verbs of motion. In contrast to verbs of motion, where English verbs seem to vastly outnumber Spanish ones, the Spanish translators used a slightly higher number of specific verbs of saying (56 Spanish verbs vs 46 English verbs; see Table 2). ${ }^{2}$

The use of the "SPEC $\rightarrow$ GEN" strategy in our corpus also differs from Slobin's data regarding verbs of motion. When translating verbs of motion, due to the lack of 
specific verbs in Spanish, translators would use a general verb for a specific one. To express manner they could resort to an "external" adverbial phrase, but this would often result in a lack of stylistic naturalness. Thus translators frequently opt for the loss of information about manner. However, very few instances of this strategy were found in our corpus (see Tables 4 and 5). There are two possible reasons for this. On the one hand, we found that Spanish specific verbs of saying outnumber English ones. On the other hand, it could be that translators feel that the "way" of saying in a dialogue is somehow more relevant than the "way" of motion in the description of a scene of movement. If you lose manner in a verb of movement, you just lose detail in the description; however, losing information in a specific verb of saying could hinder the correct interpretation of the utterance within a given context. When dealing with a dialogue between characters, the specific verbs of saying used by the narrator very often provide the reader with clues to interpret the speaker's intention, the relationships between the characters, etc.

Even more surprising was the fact that the "GEN $\rightarrow$ SPEC" strategy was used so often (see Tables 3 and 5). According to Slobin's results, in the translation of verbs of motion, translators frequently eliminated information when going from English into Spanish (translating a specific motion verb for a general one) whereas they added information when going from Spanish into English (translating a general motion verb for a specific one). What happens here is exactly the opposite. This time it is Spanish translators who add information to the scene by translating an English general verb of saying by a Spanish specific one.

This addition of information by Spanish translators indicated that they took into account frame elements which were not included in the English verbs. In contrast to verbs of motion, the extra information in verbs of saying seemed to involve other elements apart from Manner. To see what type of information was included, we tried to determine what type of frame elements were incorporated by Spanish verbs. We took as a starting point the Speech-act-frame proposed by Fillmore (Fillmore, 1997; Krüger \& Heid, 1994) in which the different frame elements which take part in the communicative event are specified:

\section{Speech-Act-Frame}

(as used by Fillmore in FrameNet and Krüger \& Heid in DELIS)

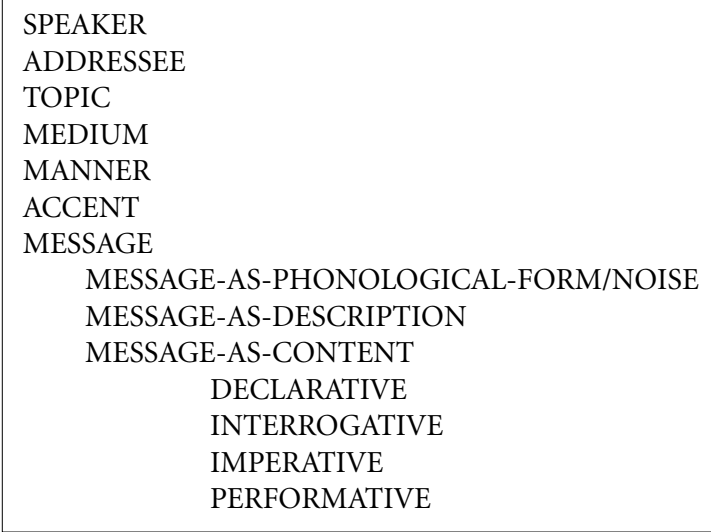


This frame was adapted to the analysis of the verbs appearing in our corpus. We proceeded to isolate the possible frame elements to which the different verbs made reference. However, the strict delimitation of meaning incorporated by each verb was not always easy. For example, one verb could make reference to different frame elements simultaneously, and in varying "degrees." As a result, some verbs have been included in more than one frame element. These were the frame elements that were incorporated by the Spanish verbs in the translation:

\section{1) MANNER:}

Some verbs incorporated "manner" into their meaning; that is, a specific way of pronouncing the message.

bromear, canturrear, clamar, croar, declamar, gritar, grunir, murmurar, exclamar, anunciar, preguntar, inquirir, lamentarse, proclamar

\section{2) INTENTION:}

A great number of the Spanish verbs in the translation incorporated information about the speaker's intention, the type of speech act, or in general, pragmatic force (illocutionary or perlocutionary).

aclarar, aconsejar, afirmar, asegurar, confesar, declarar, defenderse, explicar, felicitar, inquirir, insistir, invitar, lamentarse, ordenar, pedir, precisar, preguntar, proclamar, prometer, proponer, provocar, quejarse, rogar, sugerir.

(3) TIME:

We found that some verbs made reference to previous utterances in the on-going interactional frame. That is, sometimes a verb indicates the relation of what is being said with something that has been said before in the course of the conversation, be it a reply to a question, some further explanation of a previous point, the continuation of a nonfinished topic, etc.

añadir, contestar, responder, reponer, repetir, continuar, aclarar, admitir, citar, acceder, insistir, limitarse a contestar, terciar, empezar a hablar

DIAGRAM 2

Reference to previous frame-instances in an on-going communicative event

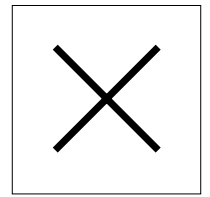

(4) TOPIC LENGTH:

Some verbs incorporate information about the length of the message. These verbs are frequently used to introduce some new referential element to the on-going conversation.

mencionar, comunicar, observar, comentar, referir, referirse, divagar

The fact that an English general verb was translated by a specific one including these frame elements showed that the translators were taking into account the whole frame when looking for an equivalent of the English verb. Let us see how Spanish translators add information with some examples: 


\section{EXAMPLE 1}

'Allie, go to bed', she said sharply to my brother (The Buddha of Suburbia: p. 4)

¡Allie, a la cama! — ordenó severa a mi hermano (El Buda de los Suburbios: p. 11)

In this example, the translator has chosen a verb (ordenar) which incorporates the illocutionary force which is implicit in the English version.

\section{EXAMPLE 2}

'Well, there are fifty-seven people at the conference, altogether', Persse said (Small World: p. 19)

Pues... en total asisten cincuenta y siete personas a este congreso - contestó Persse (El mundo es un pañuelo: p. 38)

Here, it can be seen how the translator chooses a verb (contestar) which relates the character's utterance to the on-going communicative event, indicating that it is to be interpreted as an answer to a previous question.

\section{EXAMPLE 3}

'My bloody grandson', said Anwar (The Buddha of Suburbia: p. 99)

Un nieto, joder - exclamó Anwar (El Buda de los suburbios: p. 144)

This time, the translator opts for the incorporation of the manner of saying, by using the verb exclamar.

\section{EXAMPLE 4}

- Hello, Zapp, I don't suppose you remember me.

- 'Rupert! How could I ever forget that happy face? And here comes Bob Busby, right on cue', said Morris Zapp, as a man with a less impressive beard than Philip Swallow's cantered into the bar (Small World: p. 20)

- Hola, Zapp, supongo que ya no me recuerdas.

— ¡Rupert! ¿Cómo iba yo a olvidar esa cara de felicidad? Y ahí viene Bob Busby, como si le llamara el traspunte - observó Morris Zapp, al entrar en el bar un hombre con una barba menos impresionante que la de Philip Swallow (El mundo es un pañuelo: p. 39-40)

In this example, the general verb to say has been translated by the more specific one observar. The translator has taken into account both the length of the message and the fact that Zapp's comment brings a new element into the current conversation. In this sense, the Spanish verb observar implies that the message uttered has been short, and that a new topic has been recently incorporated into the conversation.

All these examples show that translators were not simply looking for a one-toone mapping of lexical equivalents but trying to provide the reader with additional information which help them construct a coherent, sufficiently specified frame.

\section{Conclusion}

In contrast with Slobin's statement that verb-framed languages have a lower number of manner verbs than satellite-framed languages, our examples suggested that the difference between English and Spanish manner verbs of saying is not very big.

Furthermore, while in the description of motion events, translators tended to omit information when going from English into Spanish, in our study, the opposite was true. When dealing with verbs of saying, Spanish translators tended to add information, using more specific verbs. This indicated that translators do not look for 
isolated lexical equivalents of each verb. They rather take into account the interactional frame which the verb activates, the whole contextual frame that is built throughout the narration, and knowledge about interactional frames stored in their long-term memory. Translators tended to supply additional information which was taken from their evaluation of the global interactional frame, regardless of the verb used in the original version.

Though our findings here are tentative, and further investigation with a bigger corpus would be necessary, the differences between the two languages seemed to indicate differences in the narrative styles of English and Spanish. English also has a high number of specific verbs of saying; however, it seems to be a conventional feature of English dialogues to use profusely the general verb to say, leaving to the reader the inference of the specific role that the utterance plays in the interaction frame. On the contrary, in Spanish dialogues, the continued repetition of the general verb decir results in a lack of stylistic naturalness, and translators prefer to look for variants, by incorporating to the verb information surrounding the communicative event.

\section{NOTES}

1. S-language stands for "satellite-framed language" and V-language for "verb-framed language"

2. This verb seems to contain some stylistic/register information lacking in other verbs in this group (hablar, decir, contar); however, we have excluded this type of information from our study. Without this information, charlar still makes reference to the same frame elements as the other general verbs: basically Speaker and Addressee.

\section{REFERENCES}

Aske, J. (1989). "Path Predicates in English and Spanish: A Closer Look." Proceedings of the Fifteenth Annual Meeting of the Berkeley Linguistics Society, Berkeley: Berkeley Linguistics Society, pp. 1-14.

Baker, Collin F., C. J. Fillmore and J. B. Lowe (1998). "The Berkeley FrameNet Project.” In COLING-ACL '98 Proceedings of the Conference held August 10-14, 1998, in Montreal, Canada, pp.86-90.

Fillmore, C. 1982. "Frame Semantics." In Linguistic Society of Korea (ed.) Linguistics in the Morning Calm, Seul: Hanshin, pp. 111-138.

Fillmore, C. 1997. "The FrameNet Project." Paper available in Internet (http://www.icsi.com/ $\sim$ framenet).

Fillmore, C. and B.T.S. Atkins (1992). "Towards a frame-based lexicon: the semantics of RISK and its neighbours." In E. KitTay \& A. Lehrer (eds) Frames, Fields and Contrasts: new essays in semantics and lexical organization. Hillsdale (NJ): Lawrence Erlbaum Associates, pp. 75-102.

Fillmore, C., and B.T.S. AtKins (1994). "Starting where dictionaries stop: the challenge of corpus-lexicography." In AtKins \& ZAMPolli (eds.) Computational Approaches to the Lexicon, Oxford: Oxford University Press.

Krüger, K. and U. Heid (1994). "On the DELIS Corpus Evidence Encoding Schema (CEES)." Delivarable D-III-0 of DELIS (LRE 61.034).

Rojo, A. and J. Valenzuela (1998). "Frame Semantics and Lexical Translation: the RISK frame and its translation." Babel Volume 44, No 2, pp. 128-138.

Stobin, D. (1996) "Two ways to travel: verbs of motion in English and Spanish." In Shibatani Masayoshi, Grammatical Constructions: their form and meaning.

Stobin, D. (1997). "Mind, Code and Text." In J. Bybee, J. Haiman and S.A.Thompson (eds) Essays on Language Function and Language Type: dedicated to Talmy Givón, Amsterdam/ Philadelphia: John Benjamins, pp. 437-467. 
Talmy, L. 1991. "Path to realization: a typology of event conflation." Proceedings of the Seventeenth Annual Meeting of the Berkeley Linguistics Society, Berkeley: Berkeley Linguistics Society, pp. 480-519.

Novels

Amis, M. (1984). Money, London: Penguin Books (1985). Dinero, trans. Enrique Murillo, Barcelona, Editorial Anagrama, 1988.

Auster, P. (1992). Leviathan, New York: Penguin Books (1992). Leviathan, trans. Maribel de Juan, Barcelona: Editorial Anagrama (1993).

Kureishi , H. (1990). The Buddha of Suburbia. London/Boston, Faber and Faber (1990). El Buda de los Suburbios, trans. Mónica Martín Berdagué, Barcelona: Editorial Anagrama, 1992.

Lodge, D. (1984). Small World. London, Penguin Books (1985). El Mundo es un pañuelo trans. Esteban Riambau Saurí, Barcelona, Versal, 1989. 